\title{
KONSEP MASYARAKAT DAN NEGARA TAUHIDI DALAM PEMIKIRAN POLITIK MURTADHA MUTHAHHARI
}

\author{
Sabara \\ Balai Penelitian dan Pengembangan Agama Makassar \\ Email: barackfilsafat@yahoo.co.id
}

\begin{abstract}
Abstrak
Tulisan ini merupakan upaya meneliti pemikiran Murtadha Muthahhari, khususnya dalam gagasan-gagasan politiknya berkenaan dengan masyarakat dan negara. Meneliti pemikiran poltiik Murtadha Muthhari pada tulisan ini dikembangkan ke dalam 3 rumusan masalah yaitu; bagaimana konsepsi pandangan dunia Tauhid menurut Murtadha Muthahhari?, bagaimana konsep masyarakat Tauhidi menurut Murtadha Muthahhari?, dan bagaimana pandangan Murtadha Muthhhari tentang negara?. Murtadha Muthahhari adalah sosok ulama-filosof Iran kontemporer yang ikut andil sebagai ideolog dan arsitek revolusi Islam Iran tahun 1979. Pandangan dunia Tauhid menjadi dasar dari keseluruhan pemikiran dan ideology revolusoner Murtadha Muthahhari. Pandangan dunia Tauhid bermakna alam semesta berkutub tunggal, berpusat pada yang Tunggal dan alam semesta pada hakekatnya berasal dari atau milik Allah dan akan kembali kepadaNya. Allah adalah tujuan yang kepadaNya seluruh eksistensi bergerak secara bersama dan Dia pula yang menentukan arah tujuan dari seluruh semesta termasuk manusia. Masyarakat Tauhidi adalah implementasi pandangan dunia Tauhid pada ranah sosiologis yang bermakna suatu ikatan sosial di mana penguasa tertinggi adalah Allah dan rakyatnya diperlakukan secara sama sesuai dengan perintah-perintah Allah. Masyarakat Tauhidi meniscyakan egalitarianisme dan keadilan sebagai prinsip. Pandangan politik Muthahhari berorientasi pada sistem negara teo-demokrasi yang menekankan bahwa Allah adalah penguasa tertinggi. Manusia dengan prinsip independensi dan nilai ikhtiarinya memiliki hak untuk ikut andil dalam menentukan arah negara dengan tetap berdasarkan pada prinsip egalitarianisme dan keadilan serta hukum-hukum Ilahi.
\end{abstract}

\section{Kata Kunci:}

Murtadha Muthahhari, Pemikiran Politik Islam, Masyarakat Tauhidi

\begin{abstract}
This paper was an attempt to examine the thoughts of Murtadha Mutahhari, especially in his political ideas regarding society and the state. Examining the political thoughts of Murtadha Muthhari in this paper is developed into 3 problem formulations namely; what is the conception of Tauhid's worldview according to Murtadha Mutahhari? what is the concept of Tauhidi society according to Murtadha Mutahhari? and how is Murtadha Muthahhari thought about the state? Murtadha Mutahhari was a figure of contemporary Iranian ulama-philosopher who took part as an ideologist and architect of the 1979 Iranian Islamic revolution. Tauhid's worldview forms the basis of the whole thought and ideology of Murtadha Mutahhari revolutionary. Monotheistic worldview meant a single-pole universe, centered on the One and the universe essentially come from or belongs to Allah and will return to Him. Allah was the objective to which all
\end{abstract}


existence moved together and He also determined the direction of the objective whole universe, including humans. Tauhidi society is the implementation of Tauhid's worldview in the sociological domain which means a social bond where the supreme ruler is God/Allah and his people are treated equally according to God's commands. The Tauhidi people regard egalitarianism and justice as principles. Mutahhari's political views were oriented towards a theo-democratic state system which emphasized that Allah is the supreme ruler. Humans with the principle of independence and the value of their endeavors have the right to take part in determining the direction of the state while remaining based on the principle of egalitarianism and justice and divine/ilahi laws.

\section{Keywords:}

Murtadha Muthahhari, Islamic Political Thought, Tauhidi Society

\section{Pendahuluan}

Tanggal 11 Februari 1979 sebuah peristiwa besar terjadi dan cukup besar pengaruhnya dalam perubahan konstalasi politik dunia di abad ke XX Revolusi Islam Iran yang dipimpin oleh seorang ulama sepuh berumur 77 tahun bernama Ayatullah Khomeini berhasil mengakhiri masa panjang hampir tiga milenium kekuasaan feodalisme di tanah Persia yang hingga awal tahun 1979 dikuasai oleh Dinasti Pahlevi. Ayatullah Khomeini bersama para ulama dan tokoh Iran lainnya berhasil mengorganisir rakyat Iran untuk melakukan sebuah revolusi atas nama Islam yang kekuasaan Reza Pahlevi dan dominasi politik Amerika Serikat di Iran. Di masa Syah (tahun 1945-1979), Iran menjadi "Posko-Luar" bagi imperialisme Amerika di kawasan Timur-Tengah, selain itu Syah Iran juga mengukuhkan diri dalam Bahasa Persia sebagai gendarme atau polisi bagi negara-negara Arab konservatif yang menyambut seluruh kebijakan Syah dengan antusias walaupun umumnya kebijakan sangat pro-Israel. ${ }^{1}$

Riza Shihbudi mengutip Gus Dur, menyebut Ayatullah Khomeini seorang tokoh ulama kontroversial yang dipuja bagaikan "malaikat" dan dibenci bagaikan "setan". Ia dibenci oleh Barat karena berhasil mengakhiri masa kekuasaan dominasi dan hegemoni Barat di Iran sebagai salah satu sekutu utamanya di Timur Tengah. Ia juga dibenci oleh rezim feodal dan diktator di Timur Tengah karena kekhawatiran akan meluasnya pengaruh revolusi Islam Iran di negara mereka. Di Dunia Islam tidak sedikit yang membenci Ayatullah Khomeini karena faktor kemazhaban yang dianutnya. ${ }^{2}$ Ia dipuja 
oleh mereka yang merindukan kebangkitan kembali semangat militansi Islam sebagai media perlawanan terhadap Barat. Ia dipuja karena keberhasilannya mengintegrasikan ajaran dan spirit Islam sehingga benar-benar aktual sebagai pilar pembawa perubahan. Ayatullah Khomeini seperti tokoh yang digambarkan oleh muridnya, Murtadha Muthahhari sebagai "orang yang memiliki daya tarik dan daya tolak". 3

Setelah revolusi akbar pada bulan Februari 1979 yang berhasil menumbangkan Syah Pahlevi, lagi-lagi Ayatullah Khomeini melakukan sebuah inovasi yang monumental dan cukup mencengangkan dunia. Beliau melakukan perubahan secara besar-besaran, bentuk negara dari monarki absolut menjadi negara republik yang berdasarkan ajaran Islam (mazhab Syiah). ${ }^{4}$ Beliau kemudian menerapkan sebuah model sistem politik pemerintahan bernama Wilayat al-Faqih di mana ulama memiliki peran sentral dalam menjalankan roda pemerintahan negara. Wilayat al-Faqih kemudian diakui sebagai salah satu gagasan besar dalam kancah politik Islam. ${ }^{5}$ Wilayat al-Faqih bukan hanya sebagai ijtihad politik yang bersifat konseptual semata namun hari ini selama empat dekade aplikatif dalam sistem politik pemerintahan Republik Islam Iran.

Kebehasilan Ayatullah Khomeini tentu saja ditopang dan didukung oleh banyak ulama Iran yang sebagian besar di antaranya adalah murid-murid beliau. Ketika Ayatullah Khomeini diasingkan ke Irak hingga ke Prancis, murid-muridnyalah yang mempropagandakan pemikiran Ayatullah Khomeini dan semangat revolusinya. Di antara murid beliau yang paling berpengaruh adalah Murtadha Muthahhari, seorang ulama sekaligus filosof Islam Iran kontemporer. Muthahhari tampil sebagai salah satu tokoh penting dalam Dewan Revolusi Iran, sebuah lembaga yang bertugas menyatukan berbagai kelompok dan berbagai ideologi yang menentang semua kebijakan Syah Pahlevi yang dianggap telah menyalahi aturan konstitusi Iran dan nilai ajaran Islam. ${ }^{6}$

Sebagai murid dari Ayatullah Khomeini, Murtadha Muthahhari, peran-perannya cukup sentral dalam membangun opini publik Iran untuk bergerak melakukan revolusi. Muthahhari adalah seorang pemikir besar yang banyak bicara tentang gagasan-gagasan keislaman dan sosial dengan berbasis pemikiran filsafat dan teologi. Sebagai sosok

${ }^{3}$ Murtadha Muthahhari, Karakter Agung Ali bin Abu Thaib (Jakarta: Yayasan Zahra, 2002), h. 28.

${ }^{4}$ Sandy Alison, Pesan Sang Imam (Bandung: al-Jawad, 2000) ,h. 11.

${ }^{5}$ Riza, Op.Cit., h. xxi.

${ }^{6}$ Achmad Chumaedi, "Pemikiran Murtadha Muthahhari tentang Negara dan Masyarakat serta Pandangannya terhadap Revolusi Islam Iran" dalam Jurnal of Goverment and Civil Society, Vol. 2, No. 1 (2018) h. 45. 
pemikir, karakteristik yang menonjol pada diri Murtadha Muthahhari adalah keluasan pemahaman dan wawasannya tentang Islam. Keluasan pemahaman tentang filsafat dan ilmu pengetahuan modern serta keterlibatan non kompromistis terhadap keyakinan dan ideologi Barat modern tersebut. Perpaduan kedalaman pengetahuan tentang Islam, filsafat dan ilmu pengetahuan serta sikap politik yang non kompromistis menjadikannya seorang ideolog yang tangguh. ${ }^{7}$

Sumbansih terbesar dari Murtadha Muthahhari bagi keberhasilan perjuangan revolusi tersebut adalah menjadi penyiap dan peletak bagi landasan ideologi revolusi. Minat dan pengetahuan Muthahhari terhadap filsafat dan ilmu-ilmu rasional sangat berperan dalam perkembangan pemikirannya yang menjadi landasan ideologi revolusi Islam Iran. ${ }^{8}$ Beranjak dari pemikiran filsafat, ia kemudian mengembangkan gagasan tentang pandangan dunia Tauhid sebagai basis pemikiran dan ideologi mengenai berbagai hal, termasuk soal masyarakat dan negara.

Tulisan mengenai pemikiran Murtadha Muthahhari telah cukup banyak, khususnya berkenaan dengan pemikiran beliau seputar filsafat dan pandangan duia Islam. Hal yang baru dari tulisan ini adalah mengungkap gagasan-gagasan politik Muthahhari yang berkenaan dengan masyarakat dan negara. Konsepsi pandangan dunia Tauhid Murtadha Muthahhari menjadi basis paradigmatik dalam membangun gagasangagasan sosial-politiknya berkenaan dengan masyarakat dan negara.

\section{Metode Penelitian}

Tulisan ini menggunakan penelitian pemikiran tokoh, yaitu mengungkap gagasan-gagasan besar yang pernah dilahirkan oleh seorang tokoh, ${ }^{9}$ Objek kajian studi Tokoh meliputi dua hal yaitu: objek material dan objek formal. Objek Material dalam hal ini adalah pikiran salah seorang tokoh (pemikir), seluruh karyanya atau salah satunya. Objek Formal adalah pikiran atau gagasan seorang tokoh yang sedang dikaji, diselidiki dan dikaji sebagai pemikiran Islam, dengan pendekatan pemikiran. ${ }^{10}$

${ }^{7}$ Nihaya, "Sintesa Filsafat dan Teologi Murtadha Muthahhari" dalam Jurnal Suleana, Vol. 8, No.1 (2013), .h.112.

${ }^{8}$ Barsihannor, "Murtadha Muthahhari" dalam Jurnal Al-Hikmah, Vol. 12, No. 1 (2011), h. 1-2.

9Syahrin Harahap, Metodologi Studi Tokoh Pemikiran Islam (Jakarta: Istiqamah Mulya Press, 2006), h. 4.

${ }^{10}$ Ibid, h. 36 
Penelitian atau kajian studi tokoh menggunakan pendekatan historis, yaitu melihat sang tokoh sebagai manusia sejarah dan mengeksplorasi bigrafi serta pemikirannya berdasarkan lingkup dan situasi kesejarahannya. Pendekatan lain adalah sesuai konteks gagasan tokoh tersebut yang diteliti. Tokoh yang diteliti dalam tulisan ini adalah Murtadha Mutahhari, dengan demikian pendekatan historis berkenaan dengan sejarah hidup dan kondisi sosio-politik Iran di masa-masa kehidupan dan perjuangannya tak bisa dilepaskan dari konteks penulisan. Pendekatan politik menjadi penekanan berikutnya, karena tulisan ini mengeksplorasi gagasan politik Muthahahri yang berkenaan dengan masyarakat dan negara.

\section{Biografi Singkat Murtadha Muthahhari}

Murtadha Mutahari adalah seorang filosof, ulama, sufi, teolog dan pemikir serta tokoh politik Syiah kontenporer, Muthahhari juga salah seorang ideolog dan arsitek revolusi Islam Iran. Muthahhari lahir tanggal 2 Februari 1920 M yang bertepatan dengan tahun 1338 Hijriyah di sebuah desa dekat Kota Masyhad bernama Fariman,. Masyhad merupakan salah satu kota di Iran yang dianggap suci oleh pengikut Syiah Imamiyah karena di kota tersebut Ali bin Musa al-Ridha Imam Syiah yang kedelapan dimakamkan. Ayahnya, Muhammad Husein Muthahhari adalah ulama yang cukup terkemuka di kalangan Muslim Syiah Iran pada awal abad 20. ${ }^{11}$

Murtadha Muthahhari dibesarkan dalam asuhan ayahnya hingga berusia 12 tahun. Pada waktu itu Muthahhari memulai belajar Islam pada jenjang formal di Masyhad. Kota Masyhad pada waktu itu sedang mengalami kemunduran, karena alasanalasan internal dan karena bebera[a faktor eksterenal, utamanya karena tekanan-tekanan rezim Syah Pahlevi, Di Kota Masyhad Muthahhari menemukan kecintaan besarnya kepada filsafat, teologi, dan tasawuf (irfan). ${ }^{12}$

Murtadha Muthahhari adalah murid utama dan terdekat dari dua tokoh besar Syiah Iran pada masa itu, yaitu Allamah Thabaththba"I (seorang filosof dan ahli tafsir) dan Ayatullah Khomaeni. Muthahhari berguru pertama kali pada ayahnya sendiri hingga beliau berusia 12 tahun. Menginjak usia tersebut Murtadha Muthahhari mulai

\footnotetext{
${ }^{11}$ Murtadha Muthahhari, Kritik Islam Terhadap Materialisme (Jakarta: al-Huda Islamic Centre, 2001), h. 9.

${ }^{12}$ Haidar Bagir, Murtadha Muthabhari: Sang Mujabid Sang Mujtabid (Bandung:Yayasan Muthahhari, 1998), h.28.
} 
belajar ilmu-ilmu agama di hawzah (pesantren) ilmiah di Kota Masyhad. Muthahhari menunjukkan minat yang cukup besar pada filsafat, khazanah ilmu-ilmu rasional serta irfan (tasawuf atau gnosisme Syiah). Pertama kali beliau belajar filsafat dan khazanah ilmu-ilmu rasional lainnya pada Mirza Mehdi Syahidi Razawi hingga gurunya tersebut wafat. Setelah itu beliau meninggalkan Masyhad untuk pergi ke kota Qum guna melanjutkan studi agamanya pada hawzah ilmiah di kota para Mullah tersebut. ${ }^{13}$

Ketika usia yang masih belia, Murtadha Muthahhari telah mengajar beberapa mata kuliah di antaranya mantiq, filsafat, fikih, dan teologi (ilmu kalam) di fakultas Teologi Teheran University. Di universitas tersebut, Muthahhari juga sempat menjabat sebagai ketua jurusan filsafat. ${ }^{14}$ Muthahhari adalah seorang sdengan minat yang sangat besar kepada filsafat dan bidan-bidang ilmu rasional (burhany). Bagi Muthahhari, filsafat tidak hanya sekadar untuk kepentingan berpolemik atau sekadar disiplin intelektual belaka. Menurut pandangan Muthahhari filsafat merupakan sebuah pola-pola tertentu dari religiusitas dan jalan untuk memahami serta merumuskan Islam yang sesungguhnya. ${ }^{15}$

Meski berjubah dan bersurban yang menandakan bahwa dia adalah seorang ulama, namun menurut Haidar Bagir, Muthahhari adalah pembela yang gigih terhadap kebebasan berpikir dan berkeyakinan. Muthahhari memahami bahwa eksistensi Islam hanya bisa dipertahankan melalui kekuatan ilmu dan pemberian kebebasan pada ide-ide yang bertentangan dengannya, sebelum kemudian Islam memberikan bantahannya.. ${ }^{16}$ Hal ini menunjukkan posisi seorang Murtadha Muthahhari, meski beliau adalah seorang ulama, ideolog dan salah seorang arsitek revolusi Islam Iran, beliau tetaplah sebagai seorang intelektual yang mengedepankan pendekatan dialektika rasional dalam memahami, mendakwahkan dan menerapkan Islam sebagai sebuah pandangan dunia dan ideologi.

Selain mengisi kesibukan pada kegiatan-kegiatan keilmuan, Murtadha Muthahhari juga melibatkan diri pada kegiatan-kegiatan politik melwan rezim diktator Syah Pahlevi. Beliau termasuk salah seorang ideolog dan propagandis penting dalam

\footnotetext{
${ }^{13}$ Muhsin Labib, Para Filosof Sebelum dan Sesudah Shadra (Jakarta:al-Huda Islamic Center, 2005), h. 278.

${ }^{14}$ Murtadha Muthahhari, Mengenal Ilmu Kalam (Jakarta: Pustaka Zahra, 2002), h. 7.

${ }^{15}$ Hamid Algar, "Hidup dan karya Murtadha Muthahhari", dalam Pendahuluan buku Murtadha Muthahhari, Filsafah al-Hikmah: Pengantar Pemikiran Shadra (Bandung : Mizan, 2002), h. 30.

${ }^{16}$ Haidar, Op.Cit.,h. 13.
} 
sejarah revolusi Islam Iran yang dipimpin oleh Ayatullah Khomeini. Murtadha Muthahhari mengawali konfrontasi politiknya yang pertama dan secara terbuka pada tanggal 6 Juni 1963. Secara serius dan terbuka Muthahhari menyatakan dirinya sebagai salah seorang pengikut Ayatullah Khomeini, baik secara politis maupun intelektual. Muthahhari tampil di tengah-tengah masyarakat Iran dengan menyebarkan seruanseruan politik Ayatullah Khomeini dan mendesak masyarakat iran untuk memberikan dukungannya yang disampaikan melalui khutbah. ${ }^{17}$ Karena aktivitas politiknya tersebut, Muthahhari akhirnya beberapa kali ditangkap dan dipenjara oleh rezim pemerintahan Syah Pahlevi.

Melalui aktivitas politiknya beliau terlibat di berbagai organisasi politik yang berhaluan revolusioner di antaranya Persatuan Ulama Militan, sebuah organisasi yang menghimpun kekuatan ulama Syiah Iran yang bertujuan untuk mendukung seruan revolusi Islam Ayatullah Khomeini dan menggulingkan kekuasaan rezim Syah Reza Pahlevi. Kontribusi dan dedikasi besar Muthahhari berikan demi mendukung gerakan revolusi Islam, membuat Muthahhari menjadi sangat dekat dekat tokoh Ayatullah Khomeini. Pada tanggal 12 Januari 1979, tepat sebulan menjelang terjadinya Revolusi Islam Iran, Muthahhari ditunjuk sebagai ketua Dewan Revolusi bersama dengan beberapa ulama Syiah lainnya, seperti Ayatullah Javad Bahonar dan Ayatullah Husein Behesyti. $^{18}$

Aktivitas politik Muthahhari yang cukup radikal dalam mendukung cita-cita revolusi Islam mengantarkan beliau pada kesyahidannya tanggal 1 Mei 1979 (hampir tiga bulan setelah revolusi Islam). Muthahhari ditembak oleh kelompok furqani (kelompok Syiah garis keras) yang tidak suka dengan pemikiran dan garis politiknya. Muthahhari wafat setelah memimpin rapat Dewan Revolusi di rumah Dr. Tadullah Shahabi. Sebutir peluru bersarang tepat dikepalanya dan menembus kelopak matanya. ${ }^{19}$ Ayatullah Khomeini, selaku pemimpin tertinggi revolusi Islam tak kuasa menahan tangis dan kesedihannya yang mendalam ketika wafat Muthahhari. Kesedihan Khomeini sangat mendalam dibandingkan ketika anak kandungnya sendiri Sayyid Mustafa Khomeini Syahid dibunuh oleh agen rezim Syah Pahlevi.

${ }^{17}$ Murtadha, 2001, Op.Cit., h. 10.

${ }^{18}$ Ibid, h. 10-11.

${ }^{19} \mathrm{Ibid}$. 
Murtadha Muthahhari tak dapat dipisahkan dari dunia pemikiran dan filsafat Islam. Hasil-hasil pemikirannya hampir mencakup seluruh bidang keilmuan yang relevan dengan kebutuhan umat Islam dan demi kemajuan peradaban Islam di dunia. Karya-kartya Murtadha Muthahhari yang telah diterbitkan, baik dari hasil ceramahceramahnya maupun tulisan beliau cukup banyak. mencakup lebih dari 200 judul dari berbagai bidang ilmu, seperti filsafat, kalam, sejarah, sosiologi, antropologi, etika, ushul fiqh dan fikih, hukum Islam, akhlak, irfan (tasawuf), sejarah, politik, serta ekonomi. ${ }^{20}$

\section{Pembahasan}

\section{Konsep Pandangan Dunia Tauhid}

Manusia dalam menjalani kehidupannya sangat bergantung pada pola atau kerangka pikir yang kemudian disebut pandangan dunia atau world view. Tingkah laku dan arah tujuan hidup sangat ditentukan oleh bagaimana pandangan dunianya tersebut. Secara sederhana pandangan dunia adalah kerangka yang dibuat untuk melihat dunia dan berbagai kejadian yang menyertainya. Berbagai kejadian dan peristiwa tersebut kemudian oleh manusia diberi makna dalam kerangka ini. ${ }^{21}$ Menurut Murtadha Muthahhari, pandangan dunialah yang kemudian menjadi dasar dari ideologi yang dianut oleh setiap individu dan golongan. Perbedaan pada ranah ideologi yang dianut oleh setiap manusia didasarkan pada perbedaan dalam hal menyusun kerangka pandangan dunia tersebut. Menurut Muthahhari pandangan dunia, adalah bentuk dari sebuah kesimpulan, penafsiran, dan hasil kajian yang ada pada diri seseorang berkenaan tentang Tuhan, alam semesta, manusia, dan sejarah. ${ }^{22}$ Pandangan dunia kemudian bertransformasi dan membentuk ideologi sebagai pelatak keyakinan dan cita-cita yang dianut oleh kelompok masyarakat tertentu.

Menurut Muthahhari sebuah pandangan dunia yang sejati harus memiliki kriteria-kriteria di antaranya: dapat dideduksikan dan dibuktikan dengan didukung oleh nalar dan logika. Pandangan dunia memberi makna kepada kehidupan, membangkitkan idealisasi, antusiasme dan aspirasi, serta berorientasi untuk menguatiann dan mensucikan maksud dan tujuan sosial manusia, Pandangan dunia membangkitkan rasa

\footnotetext{
${ }^{20}$ Muhsin, Op.Cit., h. 280.

${ }^{21}$ Musa Kazhim, Belajar Menjadi Sufi (Jakarta:Lentera Basritama,2002), h. 25.

${ }^{22}$ Murtadha Muthahhari, Mengenal Epistemologi (Jakarta: Lentera, 2001), h. 17-18.
} 
komitmen dan tanggung jawab pada diri sendiri dan masyarakat. Sebagai sebuah pandangan dunia universal, pnadngan dunia Tauhid memiliki seluruh ciri yang mesti dimiliki oleh pandangan dunia yang ideal dan universal. Pandangan dunia Tauhid menurut Muthahhari adalah pemahaman bahwa alam semesta dapat maujud melalui suatu kehendak bijak dan bahwa tatanan kemaujudan berdiri di atas kebaikan dan rahmat agar semua entitas maujud dapat mencapai kesempurnaan mereka. Pandangan dunia Tauhid juga bermakna bahwa alam berkutub tunggal, berpusat pada Yang Tunggal dan bahwa alam pada hakekatnya secara absolut dari dan milik Allah dan akan kembali kepadaNya. $^{23}$

Secara psikologis, menurut Muthahhari pandangan dunia Tauhid memberikan spirit, orientasi dan makna-makna pada kehidupan manusia karena pandnaga dunia Tauhid meosisikan manusia di jalan kesempurnaan yang tak ada batasnya. Murtadha Muthahhari mengklaim bahwa pandangan dunia Tauhid adalah satu-satunya pandangan dunia yang mampu menyelamatkan manusia dari keterperosokan padalembah kesiasiaan. ${ }^{24}$ Pandangan dunia Tauhid menjadikan Allah sebagai tujuan yang kepadaNya seluruh maujud bergerak secara bersama. Sebagai kutub tunggal, Allah diyakini sebagai kutub yang menentukan arah tujuan dari seluruh semesta ini. Penyembahan terhadap Allah yang merupakan seruan terbesar dari ajaran para nabi, adalah seruan kepada seluruh manusia hanya menyembah Penguasa Tunggal di semesta raya ini. Penyembahan itu bertujuan untuk mengarahkan fokus manusia pada satu tujuan penciptaan dan untuk memercayai satu kekuatan yang paling efektif dari seluruh eksistensi. Penyembahan juga bermaksud menjadikan Allah sebagai tempat berlindung dan bergantung sepanjang hidup dan sejarah. ${ }^{25}$

Manusia sebagai makhluk sosial dan dalam kehidupan sosialnya membawa ribuan problem bagi dirinya yang tak dapat ia pecahkan sendiri. Karena sebagai makhluk sosial manusia tak bisa lepas dari keterkaitan pada yang lain. Oleh karena itu, kebahagiaan manusia, harapannya, standar moral, alur dan arah jalan hidup, pilihan pada sarana dan instrumen kehidupan saling berjalin-kelindan dan saling meniscayakan dengan sesamanya. Manusia dalam memilih dan melalui jalan hidupnya sangat

\footnotetext{
${ }^{23}$ Murtadha Muthahhari, Pandangan Dunia Taubid (Bandung: Yayasan Muthahhari, 1994), h. 18-19. ${ }^{24}$ Ibid, h. 20-21.

${ }^{25}$ Lihat Ali Syari'ati, Agama Versus "Agama” (Jakarta: Pustaka Hidayah, 2000), h. 29.
} 
bergantung pada sesamanya. Manusia mesti mencari jalan kebahagiaannya di jalan yang juga membawa masyarakatnya pada kebahagiaan dan kesempurnaannya. ${ }^{26}$ Karena itulah pandangan dunia Tauhid kemudian memiliki impliaksi sosial sebagai pemandu manusia sebagai satu kesatuan entitas yang kolektif.

Pandangan dunia Tauhid meyakini bahwa gerak semesta dan manusia didasarkan pada hukum qada dan qadar Allah yang menguasai seluruh alam semesta dan manusia. Sesuai dengan ketentuan qada dan qadar manusia adalah makhluk yang bebas, berwenang dan bertaggung jawab dalam menentukan nasibnya sendiri. ${ }^{27}$ Pandangan ini menunjukkan nilai independensi amnesia sebagai bukan makhluk yang bersifat determinan, melainkan memiliki kesadaran dan kehendak bebas dalam menentukan nasibnya sesuai dengan ketentuan qada dan qadar yang telah Allah gariskan dalam hukum-hukum sunnatullah.

Sebagai pandangan dunia, konsekuensi Tauhid berarti manusia hanya takut pada kekuatan tunggal, yaitu kekuatan Allah, Tuhan Yang Maha Esa,maka selain Dia adalah kekuatan yang relatif atau artifisial. Pandangan dunia Tauhid menjamin kebebasan manusia dan memuliakan manusia hanya semata padakedekatan dengan Allah (takwa). Way of life ini menggerakkan manusia untuk melawan segala bentuk dan kekuatan dominasi, hegemoni, diskriminasi, dan kezaliman manusia pada sesamanya. Tauhid memiliki esensi sebagai gagasan yang bekerja untuk mewujudkan keadilan, egalitarianisme, solidaritas sosial, dan pembebasan kemanusiaan. ${ }^{28}$

Pandangan dunia Tauhid secara substantif menngimplementasikan nilai-nilai pandangan ketuhanan tidak hanya sekadar pemahaman yang bersifat teologis semata, melainkan implementatif menjadi sebuah konstruksi teologi yang bersifat sosial. Keimanan kepada Allah sebagai satu-satunya Tuhan direfleksikan ke dalam nilai dan sikap sosial yang Tauhidi dalam artian meyakini manusia sebagai kesatuan yang egaliter. Egaliterianisme dan keadilan menjadi basis nilai dan perspektif dalam mengimplementasikan Tauhid secara efektif pada ranah sosial.

Karena mengmani Tauhid tidak sebatas keyakinan yang bersifat teologis an sich maka syirik sebagai kebalikan dari Tauhid tentunya selain bersifat teologis juga bersifat

${ }^{26}$ Murtadha Muthahhari, Manusia dan Alam Semesta (Jakarta: Lentera Basritama, 2002), h. 34.

${ }^{27}$ Murtadha, 1994, Op.Cit., h. 23.

${ }^{28}$ Eko Supriyadi, Sosialisme Islam: Pemikiran Ali Syariati (Yogyakarta: Pustaka Pelajar, 2003), h. 166. 
sosiologis. Implikasi logis dari pandangan dunia Tauhid adalah meyakini bahwa syirik adalah menerima kondisi masyarakat yang penuh kontradiksi dan diskriminasi sosial, serta mengakui adanya pengotak-kotakan atau pelapisan dalam masyarakat. Kegagalan dalan penerapan keadilan juga sebagai bentuk syirik sosial. Oleh karena itu, pandangan dunia Tauhid meniscayakan sebuah perjuangan menuju masyarakat yang egaliter dan berkeadilan tanpa diskriminasi dan penindasan.

\section{Konsep Masyarakat Menurut Murtadha Muthahahri}

Murtadha Muthahhari menggagas konsep masyarakat yang memiliki dasar dan orientasi yang bersifat metafisis. Postulat Muthahhari dalam membangun konsepnya tentang masyarakat, yakni dari metafisiss dan kembali ke metafisis (inna lillahi wa inna ilaihi rajiun). Muthahhari mengkritik konsep-konsepsi masyaraat yang ditawarkan oleh pemikir Barat. Muthahhari mengkritik pandangan individualisme Barat yang menekankan bahwa hanya individu sebagai entitas yang riil atau sebaliknya teori sosialisme yang menekankan entitas riil hanya masyarakat. Bagi Muthahhari individu dan masyarakat adalah sama-sama fundamental. Eksistensi individu tidak menjadi hilang dalam eksistensi masyarakat dan eksistensi masyarakat seperti yang terjadi pada persenyawaan kimiawi. Muthahahri juga mengkritik konsep dasar masyarakat yang hanya menekankan pada ikatan materialisme. Bagi Muthahhari masyarakat didasarkan pada ikatan-ikatan yang lebih bersifat batin dibandingkan fisis dan sebagai satu kesatuan kolektif fmenuju kesempurnaan bersama sebagai sesama manusia ciptaan Allah. $^{29}$

Muthahhari mengkritik secara filsoofis dan menilai konsep masyarakat yang diajukan oleh pemikir Barat sebagai konsep yng begitu rapuh dan tidak memiliki dasar yang kokoh. Muthahhari menawarkan alternatif baru dalam mendefinisikan hakekat masyarakat sebagaimana yang ia pahami menurut pandangan Islam. Sebagai seorang pemikir, Muthahhari tidak hanya mendasarkan pikiran-pikirannya pada uraian yang rasional an sich melainkan senantiasa merujuk pada ayat-ayat Alquran dan hadis sebagai sumber inspirasi dan refrensinya. Menurut pandangan Muthahhari, Islam juga memberikan keterangan tentang masyarakat dan individu yang masing-masing memiliki

${ }^{29}$ Lihat Murtadha,2002, Op.Cit., h. 262-266. 
kriterianya. Sebagaimana ayat dalam Alquran, yang memiliki konotasi tentang individu (al-insan/man) dan masyarakat (an-nas/society)

Murtadha Muthahhari berpandangan, manusia diciptakan cenderung mengikuti keseluruhan dan kesempurnaannya. Hakikat dasar penciptaan manusia sejatinya bersifat sosial, halini dimungkinkan agar misi Ilahi terjawantahkan di muka bumi untuk menciptakan manusia sebagai khalifah-Nya. Tujuan diturunkannya agama untuk mendidik akhlak manusia agar bisa mencapai kesempurnaannya sebagai hamba. ${ }^{30}$ Kesempurnaan hanya bisa diraih dengan adanya suatu sistem bersama mengenai adat dan hukum yang mengarahkan setiap individu untuk mencapainya. Sistem adat, dan hukum yang dimaksud oleh Muthahhari adalah yang mencerminkan nilai-nilai keIlahian atau nilai-nilai ketuhanan. ${ }^{31}$ Sistem hukum dan adat ini merupakan media yang mengantarkan manusia pada kesempurnaannya baik sebagai makhluk individu maupun secara bersama sebagai makhluk sosial.

Menurut Muthahhari, Masyarakat adalah sekelompok manusia yang terjalin erat pada suatu sistem tertentu, tradisi tertentu, konvensi dan hukum tertentu yang sama, serta mengarah pada kehidupan bersama secara kolektif. Kehidupan kolektif yang dimaksud bukan bermakna kolektivitas geografis di mana adanya sekelompok orang yang hidup berdampingan di satu daerah tertentu, memanfaatkan iklim yang sama, dan mengomsumsi jenis makanan yang sama. Muthahhari menggunakan analogi, pepohonan di sebuah kebun hidup saling berdampingan, menggunakan iklim yang sama, dan mengkomsunsi makanan yang sama. Demikian pula, kawanan rusa yang makan rumput bersama dan bergerak bersama-sama. Namun, keduanya baik pepohonan maupun kawanan rusa itu tidak hidup kolektif ataupun membangun sebuah masyarakat. $^{32}$

Masyarakat disatukan oleh kebutuhan bersama serta ikatan-ikatan tertentu dalam kehidupan manusia yang akhirnya menyatukan manusia dan memberi rasa kesatuan pada setiap individu. Muthahhari menjelaskan hal tersebut dengan memberi analogi seperti para penumpang yang tengah bepergian bersama dalam satu kendaraan yang memiliki tujuan yang sama. Masyarakat ibarrat penumpang tersebut sama semuanya

\footnotetext{
${ }^{30}$ Murtadha Muthahhari, Manusia dan Agama (Bandung: Mizan,2007), h. 65.

${ }^{31}$ Murtadha Muthahhari, Masyarakat dan Sejarah (Yogyakarta: Rausyan Fikr Institute, 2012), h. 6.

${ }^{32} \mathrm{Ibid}$, h. 5.
} 
berharap untuk tiba di tujuan dengan selamat serta bersama-sama menerima nasib yang diberikan oleh Allah. ${ }^{33}$

Berdasarkan paparan tersebut, masyarakat merupakan satu kesatuan utuh yang tidak dibatasi oleh sekat geografis maupun iklim, bahkan masyarakat sejatinya tidak dibatasi oleh sekat-sekat adat dan tradisi atau hukum yang bersifat spasial. Bagi Muthahhari masyarakat adalah kesatuan global yang diatur oleh suatu sistem adat dan hukum yang global pula. BagiMuthhari masyarakat sejatinya adalah satu, jika pun ada perbedaan pada sistem hukum, adat maupun budaya hal tersebut bersifat sekunder dan bukan substansi. Argumen lainnya untuk meyakinkan bahwa masyarakat sejatinya adalah satu menurut Muthahhari berkenaan dengan tujuan evolusioner manusia, seandainya masyarakat itu banyak maka tujuan evolusioner manusia juga banyak, sedangkan tujuan evolusioner manusia sejatinya hanyalah satu, yaitu menuju kesempurnaan yang bersifat Ilahi. ${ }^{34}$

Secara pandangan ontologis, masyarakat adalah satu dan tujuan aksiologisnya adalah satu pula. Basis ontologis dan tujuan aksiologis tersebut selain bersifat metafisis tentu juga berimplikasi pada aspek fisis. Kesatuan kemanusiaan sebagai keniscyaan dari pandangan dunia Tauhid meniscayakan kemanusiaan yang egaliter dan berkeadilan tanpa stratifikasi kelas. Kesatuan tujuan aksiologis manusia meniscyakan kesatuan tujuan fisis bersama didasarkan pada konsep egalitarianisme dan keadilan, yaitu tercapainya kemaslahatan bersama manusia sebagai entitas bersama yang bernama masyarakat. Hal iniah yang dimaksud masyarakat Tauhidi yaitu masyarakat yang satu dan memiliki satu tujuan evolusioner yang sama baik secara batin maupun lahir. Jalan untuk pencapaian tujuan evolusioner bersama tersebut adalah agama yang mendasarkan seluruh ajaran dan nilainya pada kepercayaan akan keesaan Allah.

Masyarakat Tauhid adalah suatu lembaga di mana penguasa tertinggi adalah Allah dan rakyatnya diperlakukan secara sama sesuai dengan perintah-perintah Allah. Semua manusia sama dalam pandangan hukum. Semua prasangka, egoisme dan perselisihan disingkirkan untuk kemaslahatan bersama. ${ }^{35}$ Dengan demikian masyarakat Tauhidi adalah masyarakat yang egaliter dan bersendikan asas-asas keadilan dan

${ }^{33} I$ Ibid, h. 7.

${ }^{34}$ Murtadha, 2002, Op.Cit., h. 292.

${ }^{35}$ Muchsin Qira'ati, Taubid: Pandangan Dunia Alam Semesta (Jakarta: CV. Firdaus,1991), h. 64. 
kemaslahatan bersama. Masyarakat Tauhidi adalah masyarakat yang menggambarkan kesatuan manusia yang setara tanpa penindasan atau diskriminasi dalam bentuk apa pun.

\section{Konsep Negara}

Pemikiran Murtadha Muthahhari tentang negara sangat dipengaruhi oleh sikap kritisnya terhadap sistem neraga Iran di masa Syah Pahlevi yang sangat feudal dan otoriter. Rezim pemerintahan iran di bawah kepemimpinan Syah Pahlevi yang sangat jauh dari nilai-nilai Islami memantik ulama dan pemikir Iran untuk melakukan revolusi kemudian menyusun suatu sistem dan bentuk negara yang berrorientasi pada keadilan dengan didasarkan pada sistem pemerintahan Islam. Muthahhari merupakan murid dan loyalis setia Ayatullah Khomeini, sehingga pikiran-pikiran beliau tentang konsep negara sejalan dengan konsep Ayatulah Khomeini, yaitu sebuah model negara teodemokrasi dengan sistem pemerintahan Wilayat al-Faqih.

Menurut Murtadaha Muthahhari, negara merupakan lembaga yang di dalamnya terdapat ketergantungan antar sesama manusia untuk mewujudkan kedamaian dan harmoni. Berdasarkan asumsi tersebut, Muthahhari memandang negara sebagai sebuah lembaga yang mengatur masyarakat untuk lebih memperjuangkan nilai-nilai demokrasi. Sistem pemerintah Islam merupakan solusi untuk mencapai nilai-nilai demokrasi yang sesungguhnya. Berdasarkan pandangan dunia Tauhid, sistem pemerintahan Islam menempatkan kedaulatan rakyat yang terbatas di bawah kekuasaan Allah, karena tiap peraturan yang berlaku harus sesuai dengan prinsip dan syariat Islam. Terbentuknya pemerintahan dan pelaksanaannya harus sesuai kehendak rakyat. Pemerintah ialah wakil masyarakat untuk mengurusi kepentingan agama dan dunia agar tak bertentangan dengan ajaran dalam Alquran maupun Hadis. ${ }^{36}$ Inilah yang dimaksud sistem pemerintahan Islam yang kemduian diterapkan di Iran sebagai sistem pemerintahan dengan bentuk teodemokrasi. Sistem teo-demokrasi didasarkan pada modifikasi sistem kepemimpinan imamah melalui sistem politik Wilayat al-Faqih yang menyentuh 3 sendi sistem pemerintahan republik, yaitu eksekutif, legislatif dan yudikatif. ${ }^{37}$

Konsep negara menurut Menurut Muthahhari, didasarkan pada pandangan filosofisnya mengenai masyarakat yang mempunyai hukum dan prinsip kolektif yang

${ }^{37}$ Lihat Yamani. Filsafat Politik Islam: antara al-Farabi dan Khomeini (Bandung: Mizan,2002). 
menentukan jatuh bangunnya yang bersinergi dengan arus gerak sejarah tertentu. Karena hal tersebutlah kemudian terbangun konsensus bersama dalam upaya merealisasikan hukum sehingga dapat mengatur hajat hidup masyarakat melalui sebuah lembaga yang kemudian disebut sebagai negara.

Menurut Murtadha Muthahhari, negara merupakan sebuah lembaga yang di dalamnya manusia saling bergantung satu sama lain guna merealisasikan harmoni dan kerukunan. Berdasarkan pandangan tersebut, beliau memandang negara merupakan sebuah organisasi yang mengatur tata kehidupan masyarakat untuk lebih memperjuangkan nilai-nilai demokrasi. Demokrasi dalam suatu revolusi, demokrasi diusung lebih ditujukan bagi kebijakan yang berpengaruh pada masyarakat secara umum. Pemerintahan yang demokratis bisa terrealisasi melalui adanya pengakuan atas kesamaan dan kesamaan harkat dan martabat manusia yang memungkinkan masyarakat dalam berpartisipasi dalam pemerintahan melalui hak pilih. Berkenaan dengan hal tersebut, Muthahhari menyebut ideologi Islam sebagai ideologi dengan prinsip persamaan harkat dan anti diskriminasi. ${ }^{38}$ Egalitarianisme kemudian menjadi basis bagi prinsp-prinsip selanjutnya, yaitu tegaknya keadilan dan terwujudnya kemaslahatan dan kesejahteraan bersama.

Guna mewujudkan tujuan egalitarianisme manusia tersebut, maka harus didasarkan pada pandangan dunia Tauhid bahwa kedaulatan yang tertinggi adalah kekuasaan Allah yang bersifat mutlak. Pada sisi yang lain dalam kehidupan bernegara, masyarakat ideal adalah masyarakat yang mampu mewujudkan masyarakat yang egaliter dan setara tanpa membeda-bedakan status sosial dan diskriminasi dengan alas an apa pun. Dengan demikian tidak ada seorang pun individu yang mendapatkan tindakan diskriminasi dalam bentuk apa pun hanya karena perbedaan status sosialmaupun identitas lainnya. Hal ini didasarkan pada pandangan bahwa setiap manusia pada dasarnya adalah khalifah di muka bumi. Oleh karenanya, pedoman ideal dalam kehidupan bernegara yaitu melalui prinsip syura untuk menunjang terwujudnya kehidupan demokrasi. ${ }^{39}$

Guna meralisasikan iklim demokrasi dalam suatu negara, pemimpin memegang kunci peranan paling penting. Setiap masyarakat mengharapkan pemimpin yang adil, 
yaitu orang yang memimpin negara dengan ketulusan hati. Tipologi pemimpin ideal dapat dilihat pada potret kehidupan para nabi. Mereka diutus oleh Allah untuk merealisasikan kepemimpinan ilahi di muka bumi. Setelah masa kenabian berakhir, seiring wafatnya Nabi Muhammad. Maka pemimpin umat yang sah adalah yang melanjutkan khittah nabawiyah (garis kenabian). Pandangan Muthahhari ini merujuk pada keyakinan teologis Syiah yang meyakini keluarga nabi (ahlul bait) yang )ditunjuk oleh Allah untuk melanjutkan tugas kepemimpinan berdasarkan manhaj para nabi. ${ }^{40}$

\section{Kesimpulan}

Pandangan dunia Tauhid menurut Murtadha Muthahhari adalah pemahaman dan cara pandang bahwa alam semesta dapat maujud melalui suatu kehendak bijak Tatanan kemaujudan semesta berdiri di atas kebaikan dan rahmat agar semua eksistensi semesta dapat menggapai kesempurnaan mereka. Selain itu pandangan dunia Tauhid juga bermakna bahwa alam semesta berkutub tunggal, berpusat pada Allah sebagai modus eksistensi dan secara hakekat bahwa alam semesta adalah dari dan milik Allah serta semuanya akan kembali kepada Allah. Allah adalah tujuan yang kepadaNya seluruh entitas maujud bergerak secara simultan, dan Dia pula yang menentukan tujuan dari alam semesta termasuk manusia.

Masyarakat Tauhid adalah suatu lembaga di mana penguasa tertinggi adalah Allah dan rakyatnya diperlakukan secara sama sesuai dengan perintah-perintah Allah. Masyarakat Tauhidi meiscyakan egalitarianisme dan keadilan sebagai prinsip. Semua manusia sama dalam pandangan hukum. Semua prasangka, egoisme dan perselisihan disingkirkan untuk kemaslahatan bersama. Masyarakat Tauhidi adalah masyarakat yang egaliter dan bersendikan asas-asas keadilan dan kemaslahatan bersama.

Negara merupakan lembaga yang di dalamnya terdapat ketergantungan antar sesama manusia untuk mewujudkan kedamaian dan harmoni. Negara merupakan sebuah organisasi yang mengatur tata kehidupan masyarakat untuk lebih memperjuangkan nilai-nilai demokrasi. Sementara itu pemerintahan yang demokratis bisa terwujud apabila terdapat pengakuan atas kesamaan martabat manusia yang memungkinkan masyarakat menggunakan hak pilihnya. Muthahhari memiliki pandangan politik dengan

${ }^{40}$ Achmad, Op.Cit., h. 43. 
sistem negara teodemokrasi yang menekankan bahwa Allah adalah penguasa tertinggi, namun manusia dengan prinsip independensi dan nilai ikhtiyarinya memiliki hak untuk ikut andil dalam menentukan arah negara dengan tetap berdasarkan pada prinsip ajaran Islam.

\section{DAFTAR PUSTAKA}

Algar, Hamid. "Hidup dan karya Murtadha Muthahhari" dalam Pendahuluan buku Murtadha Muthahhari. Filsafah al-Hikmah: Pengantar Pemikiran Shadra. Bandung : Mizan, 2002.

Alison, Sandy. Pesan Sang Imam. Bandung: al-Jawad, 2000.

Bagir, Haidar. Murtadha Muthahhari: Sang Mujahid Sang Mujtahid. Bandung:Yayasan Muthahhari, 1998.

Barsihannor. "Murtadha Muthahhari” dalam Jurnal Al-Hikmah, Vol. 12, No. 1 (2011), h. 1-10.

Chumaedi, Achmad. "Pemikiran Murtadha Muthahhari tentang Negara dan Masyarakat serta Pandangannya terhadap Revolusi Islam Iran" dalam Jurnal of Goverment and Civil Society, Vol. 2, No. 1 (2018) h. . 33-50.

Engineer, Asghar Ali. Devolusi Negara Islam. Yogyakarta: Pustaka Pelajar, 2000.

Harahap, Syahrin. Metodologi Studi Tokoh Pemikiran Islam. Jakarta: Istiqamah Mulya Press, 2006.

Kazhim, Musa. Belajar Menjadi Sufi. Jakarta:Lentera Basritama,2002.

Labib, Muhsin. Para Filosof Sebelum dan Sesudah Shadra. Jakarta:al-Huda Islamic Center, 2005.

Muthahhari, Murtadha. Karakter Agung Ali bin Abu Thalib. Jakarta: Yayasan Zahra, 2002.

Muthahhari, Murtadha. Kritik Islam Terhadap Materialisme. Jakarta: al-Huda Islamic Centre, 2001.

Muthahhari, Murtadha. Manusia dan Agama. Bandung: Mizan,2007.

Muthahhari, Murtadha. Manusia dan Alam Semesta. Jakarta: Lentera Basritama, 2002.

Muthahhari, Murtadha. Masyarakat dan Sejarah. Yogyakarta: Rausyan Fikr Institute, 2012 . 
Muthahhari, Murtadha. Mengenal Epistemologi. Jakarta: Lentera, 2001.

Muthahhari, Murtadha. Mengenal Ilmu Kalam. Jakarta: Pustaka Zahra, 2002.

Muthahhari, Murtadha. Pandangan Dunia Tauhid. Bandung: Yayasan Muthahhari, 1994.

Nihaya. "Sintesa Filsafat dan Teologi Murtadha Muthahhari" dalam Jurnal Suleana, Vol. 8, No.1 (2013), h. 111-118.

Qira'ati, Muchsin. Tauhid: Pandangan Dunia Alam Semesta. Jakarta: CV. Firdaus, 1991.

Shihbudi, Riza. Biografi Politik Imam Khomeini. Jakarta: Gramedia Pustaka Utaama, 1996.

Supriyadi, Eko. Sosialisme Islam: Pemikiran Ali Syari'ati. Yogyakarta: Pustaka Pelajar, 2003.

Syari’ati, Ali. Agama Versus “Agama”. Jakarta: Pustaka Hidayah, 2000.

Yamani. Filsafat Politik Islam: Antara al-Farabi dan Khomeini. Bandung: Mizan,2002. 